\title{
Penguatan Nilai-Nilai Pancasila dan Keislaman di Kalangan Pelajar
}

\section{Strengthening Pancasila and Islamic Values Among Students}

\author{
Ahmad Suhendra \\ Hukum Keluarga, STISNU Nusantara Tangerang \\ Jalan Perintis Kemerdekaan II Cikokol Tangerang Kota Tangerang \\ asra.boy@gmail.com
}

\section{H Moh Mahrusillah}

Hukum Ekonomi Islam, STISNU Nusantara Tangerang Jalan Perintis Kemerdekaan II Cikokol Tangerang Kota Tangerang mohmahrusillah@gmail.com

Artikel diterima14 Juli 2019, diseleksi 3 Desember 2019, dan disetujui 10 Desember 2019

Abstrak: Gerakan radikal agama di Indonesia telah menyusup ke kalangan pelajar. Penyusupan paham itu melalui organisasi-organisasi siswa intra-sekolah dan organisasi kerohanian. Maka tidak heran, saat ini banyak kasus terorisme yang melibatkan anak sekolah SMA. Kota Tangerang sebagai salah satu daerah penyangga Ibu Kota memiliki posisi strategis, secara ekonomi, social maupun politik. Berdasarkan hasil penelitian LP3M STISNU terdapat 115 dari 155 responden yang diteliti sudah masuk terindikasi radikal. Artinya, ada 115 sekolah yang siswanya berorientasi pada radikalisme. Bentuk pengabdian kepada masyarakat terintegrasi ini diberi nama Ngaji Pancasila. Ada lima lembaga pendidikan yang menjadi lokasi pengabdian kepada masyarakat. Sebab itu dalam pelaksanaan pengabdian kepada masyarakat terintegrasi 2018 ini ditujukan pada pelajar. Metode pengabdian yang dilakukan adalah dengan wawancara, observasi dan ceramah. Adapun bentuk kegiatan dinamakan Ngaji Pancasila. Ngaji Pancasila ini Tim Pengabdian melakukan roadshow 
ke beberapa sekolah di Tangerang Raya. Di dalamnya, Tim Pengabdian memberikan rekonstruksi pemahaman tentang Pancasila, Keislaman dan Kebangsaan. Ada delapan sekolah yang dijadikan dampingan Ngaji Pancasila, yakni 1) SMK An-Nisiniyyah; 2) SMA Babussalam; 3) MA AlHikmah; 4) SMAN 20; 5) SMAN 21; 6) SMK Al-Gina; 7) MA Darussa'adah; dan 8) SMA IT Al-Husaini. Berdasarkan pengamatan di lapangan maka diperlukan adanya penguatan materi tentang Pancasila dan Keislaman

Kata Kunci: Radikalisme, Ngaji Pancasila, Pancasila, Islam, Pelajar

Abstract: The radical religious movement in Indonesia has infiltrated among the younger generation, especially students. Infiltration understand that student organizations through intra-organization and spiritual schools. It is no wonder, many current cases of terrorism involving school children high school. Tangerang city as one of the city's capital buffer has a strategic position, in the economic, social or political. Based on the results of the research there were 115 from STISNU LP3M 155 respondents researched already entered they radical. That is, there are 115 schools that their students are oriented on radicalism. The form of the integrated community named Budheg Pancasila. There are five institutions which became the location of the community. Therefore in the implementation of the community's integrated 2018 is aimed at students. The method of devotion that is done with the interview, observation and speaking engagements. As for the form of the activity is called Budheg Pancasila. Budheg Pancasila this Team Devotion do roadshow to some school in Tangerang. In it, the team's understanding of the reconstruction gave the Devotion of Pancasila, the national and Islamic. There are eight schools made dampingan Budheg Pancasila, i.e. 1) CMS's-Nisiniyyah; 2 Babussalam HIGH SCHOOL); 3) $M A$ Al-Hikmah; 4) SMAN 20; 5) SMAN 21; 6 CMS) Al-Gina; 7) MA Darussa'adah; and 8) SMA IT Al-Husaini. Based on observations in the field required the presence of the reinforcement material about Pancasila and Islam

Keyword: Radicalism, Ngaji Pancasila, Pancasila, Islam, Student 


\section{A. Pendahuluan}

Kekerasan dan teror atasnama agama menjadi keprihatinan bersama. Gerakan radikalisme yang dibungkus dengan isu agama membuat sebagian orang merasa terpanggil. Beberapa aksi terror di Indonesia dilatarbelakangi pemahaman yang keliru terhadap agama. Sebab itu, radikalisme adalah pemikiran yang dapat merusak tatanan social dalam berbangsa, bernegara, maupun beragama. Hal itu bias dilihat dari konflik yang terjadi di dunia Arab seperti Afganistan dan Suriah.

Konflik yang terjadi di dunia Arab itu berdampak baik langsung maupun tidak langsung dan kecil maupun besar. Gerakan radikalisme itu menyebar ke beberapa negara-negara lainnya, termasuk Indonesia. Konflik yang sudah digeneralisir dapat mengganggu relasi sosial keagamaan masyarakat Indonesia yang telah dibangun selama ini. ${ }^{1}$

Adanya tindakan radikal diawali dengan pemahaman yang sempit atas ajaran agama dan klaim kebenaran (truth claim). Radikal sendiri sebenarnya tidak bermasalah saat hanya bersarang dalam pemikiran para penganutnya. Tetapi, ketika radikalisme pemikiran bergeser menjadi gerakan-gerakan radikal, maka radikalisme mulai menimbulkan masalah. ${ }^{2}$

Di era disrupsi seperti saat ini, semua informasi sangat mudah masuk atau diterima dan keluar atau disebarkan. Dengan kemajuan teknologi, remaja sekolah menengah atas (SMA) sampai mahasiswa paling sering menjadi target gerakan radikal di Indonesia. Saat ini banyak kasus terorisme yang melibatkan anak sekolah SMA. ${ }^{3}$ Penyebaran ideologi radikalisme di kalangan pelajar banyak disusupi melalui organisasi intra-sekolah. Mereka sengaja direkrut untuk menyiapkan kaderisasi bagi keberlangsungan ideologi yang sejalan dengan radikalisme.

Para pakar psikologi bersepakat bahwa psikologis anak-anak remaja ini mudah berubah dan tidak pasti. ${ }^{4}$ Makanya, mereka kerap dijadikan target perekrutan penyebaran ideology tertentu. Kebanyakan mereka 
belum mengerti dan belum memiliki pegangan hidup mendasar yang membuat mereka mudah untuk diberikan pemahaman yang ekstrem dan negatif tersebut. Tahapan yang dilakukan untuk memberikan pendangkalan pemahaman terhadap mereka biasanya meragukan Pancasila dan mempertentangkannya dengan agama (Islam). ${ }^{5}$ Bahkan, ada sekolah yang mengajarkan kepada muridnya menghormat bendera merah putih merupakan bagian dari larangan agama. ${ }^{6}$

Sarwono menyatakan, gerakan radikal agama di Indonesia telah menyusup ke kalangan generasi muda, khususnya pelajar. Penyusupan paham itu melalui organisasi-organisasi siswa intra-sekolah dan organisasi kerohanian. Berbagai kelompok radikal agama memiliki kesepakatan dalam hal tidak setia membela NKRI dan Pancasila sebagai ideology pemersatu bangsa. ${ }^{7}$ Remaja dalam dunia psikologis dikenal sebagai masa pencarian jati diri. Remaja lebih mudah terpapar paham radikalisme. Dengan demikian, pencegahan radikalisme sejak dini di kalangan pelajar menjadi keniscayaan.

Problem yang muncul terkait persoalan radikalisme harus benarbenar dicermati dan diresapi bersama. Harus ada konsep atau gagasan baru dalam membudayakan dan membumikan Pancasila. Langkah ini penting dilakukan, karena selama ini proses pembudayaan masih terkesan kaku, yakni dilakukan hanya untuk kepentingan negara, khususnya aparat pemerintah, tetapi tidak memberi ruang publik untuk melakukan interpretasi dan melahirkan ide-ide yang kreatif, sehingga berdampak pada bagaimana internelisasi nilai-nilai Pancasila.

Isu radikalisme ideologi pada generasi muda sudah menjadi perhatian khusus Sekolah Tinggi Ilmu Syariah Nahdlatul Ulama (STISNU) Nusantara Tangerang. STISNU sebagai perguruan tinggi Islam berupaya untuk mendorong para dosen melakukan pengabdian kepada masarakat. Subyek dampingan dalam pengabdian ini adalah para pelajar di wilayah Tangerang, terutama siswa Sekolah Tingkat Lanjut Atas (SLTA), baik Madrasah Aliyah (MA), Sekolah Menengah Atas (SMA) maupun Sekolah Menengah Kejuruan (SMK). 
Kota Tangerang sebagai salah satu daerah penyangga Ibu Kota memiliki posisi strategis, secara ekonomi, social maupun politik. ${ }^{8}$ Penduduknya juga beragam dari aspek suku, ras dan agama. Posisinya yang strategis itu mengundang banyak orang untuk tinggal di Kota Tangerang. Sebab itu, segala paham apapun lebih besar untuk masuk ke Kota Akhlakul Karimah ini.

Dinamika kehidupan perekonomian kota ditandai dengan berkembangnya unit-unit usaha dan perdagangan termasuk pertumbuhan jumlah penduduk yang mencapai 921.848 jiwa, dengan laju pertumbuhan mencapai 8,27 \% yang diakibatkan derasnya arus urbanisasi yang pada akhirnya berpengaruh bagi kehidupan sosial politik, budaya dan perekonomian masyarakat. ${ }^{9}$

Sebab itu, obyek dampingan dalam pengabdan ini diutamakan sekolah-sekolah yang siswanya banyak terindikasi dan berorientasi radikal dan atau memiliki pemahaman kepancasilaan dan keislaman tidak komprehensif. Berdasarkan hasil penelitian LP3M STISNU terdapat 115 dari 155 responden yang diteliti sudah masuk terindikasi radikal. Artinya, ada 115 sekolah yang siswanya berorientasi pada radikalisme. MA terdiri atas 33 sekolah (Negeri/Swasta), SMA terdiri atas 53 sekolah (negeri/swasta) dan SMK terdiri atas 29 sekolah (negeri/swasta). ${ }^{10}$

Menurut survei Gerakan Nasionalis yang dilakukan Lembaga Kajian Islam dan Perdamain (LaKIP) menunjukkan, adanya penguatan radikalisme di kalangan pelajar. Sebanyak 76 persen siswa SMP/SMU seJabotabek memilih syariah ketimbang Pancasila sebagai norma pengatuh kehidupan sosial. ${ }^{11}$ Padahal pelajar merupakan penerus pemimpin Indonesa di masa depan. Pelajar adalah asset bangasa dan negara Indonesia ke depan. Jika mereka diarahkan dalam mendalami menghayati nilai-nilai Pancasila, maka ke depan dimungkinkan Pancasila itu tinggal nama saja. Sebab itu, diperlukan penerapan keilmuan dan wawasan keislaman dalam penguatan nilai-nilai kebangsaan dan kebhinekaan. Selain itu, perlu juga pemahaman korelasi antara Pancasila dan Islam, 
yakni nilai-nilai Pancasila pada dasarnya itu tidak bertentangan dengan ajaran Islam. Berdasarkan itu, fokus pendampingan dalam pengabdian masyarakat adalah memberikan pendidikan nilai-nilai Pancasila kepada pelajar di Tangerang.

Berdasarkan latarbelakang itu, maka diperlukan penguatan wawasan kebangsaan di kalangan pelajar Tangerang. Civitas STISNU Nusantara sebagai pengamalan tri darma perguruan tinggi maka diperlukan pengabdian kepada masyarakat. Maka dilakukan pengabdian masyarakat judul yang diajukan adalah PENGUATAN NILAI-NILAI KEBANGSAAN DAN PANCASILA DALAM MENANGKAL BENIH RADIKALISME DI KALANGAN PELAJAR TANGERANG.

\section{B. Identifikasi dan Rumusan Masalah}

Berdasarkan penelitian yang dilakukan Lembaga Pengembangan, Penelitian dan Pengabdian Masyarakat (LP3M) STISNU Nusantara Tangerang melakukan survei mengenai pemahaman nilai-nilai Pancasila dan Kebangsaan di kalangan pelajar di Tangerang. Di dalam survei itu yang menjadi obyek penelitian adalah populasi dalam penelitian ini adalah para pelajar tingkat SLTA yaitu tingkat Sekolah Menengah Atas (SMA) sebanyak 82 Sekolah, Sekolah Menengah Kejuruan (SMK) sebanyak 93 Sekolah dan Madrasah Aliyah (MA) sebanyak 18 Madrasah di wilayah kota Tangerang. Adapun jumlah populasi pelajar SLTA di kota Tangerang sebanyak 47.471 orang yang terdiri dari 19.105 orang tingkat SMA, 26.375 orang tingkat SMK dan 1.991 orang untuk tingkat MA. ${ }^{12}$ Dari jumlah tersebut diambil sampel sebanyak 155 responden.

Dalam survei LP3M STISNU Nusantara ingin dicapai mengenai pandangan pelajar Tangerang terhadap nilai-nilai luhur kebangsaan yang meliputi: 1) berbuat baik kepada non-muslim; 2) menyelesaikan permasalahan agama tanpa kekerasan; 3) Mengedepankan akal daripada sentimen agama dalam menyelesaikan konflik agama; 4) Hidup harus seimbang antara urusan dunia dan akhirat; 5) Menjaga solidaritas sosial 
dengan pemeluk agama lain; 6) Tidak membenarkan tindakan kekerasan terhadap mereka yang anti Islam (memusuhi Islam);7) Bersifat demokratis terhadap perbedaan pendapat; 8) Sentimen agama yang berlebihan terhadap agama lain; 9) Menyelesaikan konflik dengan cara damai, arif dan bijaksana berprinsip keadilan; 10) Menjunjung nilai-nilai keadilan dalam menyelesaikan masalah; 11) Menggunakan tindakan kekerasan dalam mencegah kemungkaran; 12) Membenarkan tindakan kekerasan atas nama jihad fi sabilillah; 13) Menyebarkan kebencian terhadap non muslim (penganut agama lain); 14) Mengajak kebaikan dengan cara damai; 15) Negara Indonesia harus berazaskan Islam, bukan Pancasila; 16) NKRI sebaiknya menjadi negara islam (Khalifah Islamiyah); 17) ISIS dan organisasi lainnya (yang mengatasnamakan islam) melakukan tindakan kekerasan terhadap orang-orang yang dianggapnya sebagai musuh islam; 18) Jihad dalam ajaran Islam adalah berperang; 19) Indonesia adalah negara kafir; 20) Nilai-nilai luhur pancasila sesuai dengan ajaran islam (Al-Qur'an \& Hadits); 21) Tindakan ISIS sesuai dengan ajaran Islam.Dari survei yang dilakukan dapat disimpulkan munculnya benih pemahaman radikalisme di kalangan pelajar dan lunturnya nilai-nilai Pancasila di kalangan pelajar. ${ }^{13}$

Berdasarkan latar belakang di atas, maka rumusan masalah dalam kegiatan yang akan dilakukan ini adalah pendampingan melalui pengabdian masyarakat dengan tajuk, Penguatan Nilai-Nilai Kebangsaan Dan Pancasila Dalam Menangkal Benih Radikalisme Di Kalangan Pelajar Tangerang.

Untuk itu masalah yang dirumuskan dalam pengabdian masyarakat ini adalah Mengapa adanya benih radikalisme di kalangan pelajar Kota Tangerang? Bagaimana menguatkan nilai-nilai Pancasila dan Kebangsaan kepada pelajar Kota Tangerang? Bagaimana menangkal radikalisme di kalangan pelajar Kota Tangerang?

Dengan diadakannya pengabdian masyarakat terintegrasi ini ada beberapa poin harapan pada dampingan. Pertama, dengan penguatan 
nilai-nilai Pancasila dan Kebangsaan, kondisi dampingan dalam hal ini siswa dapat memahami antara urgensi Pancasila dalam berbangsa dan bernegara. Kedua, para pelajar dapat memahami hubungan antara Pancasila dan Islam itu tidak bertentangan. Ketiga, para pelajar dapat mengetahui proses internalisasi nilai-nilai Pancasila dan keislaman dalam pemikiran dan tindakan.

Kegiatan pengabdian masyarakat mengenai penguatan nilai-nilai Pancasila dan Keislaman diharapkan dapat mencapat tujuan berikut. Pertama, menumbuhkan semangat kebersamaan dalam berbangsa dan bernegara yang berlandaskan Pancasila dan Bhineka Tunggal Ika.Kedua, menumbuhkan pemahaman yang tepat atas nilai-nilai Pancasila dan kebangsaan dan menguatkan rasa cinta tanah air pada setiap pelajar. Ketiga memberikan pemberdayaan berupa deradikalisasi di kalangan pelajar di Tangerang dengan menjadi fasilitator dalam penguatan nilainilai Pancasila dan kebangsaan di kalangan pelajar.

Adapun manfaat dari pengabdian kepada masyarakat ini adalah a) mendapatkan wawasan tentang hubungan agama dan negara; b) tumbuhnya rasa nasionalisme di kalangan pelajar dan pengetahuan tentang hubungan Islam dan Pancasila; c) pelajar Kota Tangerang mendapatkan pemahaman yamng komprehensi tentang nilai-nilai Pancasila dan kebangsaan serta Islam; dan d) mendorong lembagalembaga pendidikan untuk mencegah tumbuhnya benih radikalisasi di kalngan pelajar.

Pelajar adalah penerus pemimpin bangsa dan negara ini ke depan. Sebagai penerus bangsa harus tepat dalam memahami ideology bangsanya sendiri, sesuai dengan para founding father bangsa dan negara ini. Apabila mereka sudah terindikasi dengan paham radikalisme maka besar kemungkinan pergantian ideology bangsa menjadi ideology yang lain. Hal itu tentu menggangu stabilitas keamanan bangsa dan negara. 


\section{Pendorong Gerakan Radikalisme}

Radikalisme bisa dipahami politik kenegaraan yang menghendaki adanya perubahan dan revolusi besar-besaran. Makna ini cenderung positif yang bisa melahirkan kemajuan besar bagi peradaban dunia. Namun, ada pengertian lain yang menyebutkan bahwa radikalisme adalah prinsip-prinsip atau praktik-praktik yang dilakukan secara radikal. Praktik itu mencoba untuk mempertentangkan nilai-nilai yang diperjuangan atas nama agama maupun ideology tertentu dengan tatanan nilai yang sudah mapan pada saat itu. ${ }^{14}$ Dalam perkembangannya, radikal ini telah mengalami penyempitan makna menjadi negative saja. Radikal yang sudah menjadi paham (isme/radikalisme) ini yang berpotensi menjadi ancaman.

Banyak faktor yang melatarbelakangi lahirnya tindakan-tindakan radikal. Syamsul Bakri membagi faktor pendorong munculnya gerakan radikalisme ke dalam lima faktor. Pertama, faktor social-politik. Gejala agama lebih dilihat sebagai gejala social-politik dibandingkan gejala keagamaan. Kedua, faktor emosi keagamaan. Perbedaan pandangan maupun aliran yang disertai dengan truth claim (klaim kebenaran) dalam beragama memunculkan sentiment keagamaan. Sentiment ini yang dapat memicu lahirnya radikalisme agama. ${ }^{15}$

Ketiga, yang dapat melatarbelakangi munculnya radikalisme adalah faktor kultural. Adanya anti tesa terhadap budaya tertentu yang dianggap sebagai musuh yang harus dihilangkan dari bumi. Keempat, ideology anti westernisme. Westernisme merupakan suatu pemikiran yang membahayakan orang Islam dalam mengaplikasikan syariat Islam, maka muncullah gerakan anti barat. Kelima, faktor kebijakan pemerintah. Kebijakan pemerintah yang dianggap tidak adil dan menyudutkan salah satu kelompok dapat melahirkan frustasi dan kemarahan. ${ }^{16}$

Menurut Sarwono terdapat sembilan bentuk ciri radikalisme yang menyebar di kalangan pelajar. Pertama, para aktivis radikal agama menanamkan kebencian terhadap negara dan pemerntahan. Kedua, 
para pelajar diajarkan menolak menyanyikan lagu-lagu kebangsaan dan menghormat bendera. Ketiga, ikatan emosional kepada ustadz, senor dan kelompoknya lebih kuat daripada ikatan pada keluarga dan almamaternya. Keempat, kegiatan yang mereka lakukan dalam melakukan pengajian dan kaderisasi bersifat tertutup. Kelima, para pelajar anggota gerakan radikal diharuskan membayar uang penebusan dosa. Keenam, mengenakan pakaian secara khas yang menurut mereka adalah versi Islami. Ketujuh, menganggap kafir dan fasik orang lain yang belum bergabung dengan kelompoknya. Kedelapan, enggan mendengarkan ceramah dari kelompok lain. Kesembilan, sebagian dari palajar bersikukuh mengikuti gerakan radikalisme agama. ${ }^{17}$

Pancasila dan agama tidak saling menegasikan. Pancasila bukan sebuah agama, dan tidak bertentangan dengan agama. Dalam sejarahnya, Pancasila lahir dan menjadi ideology negara Indonesia itu melibatkan tokoh agama, sebut saja Hadratusyaikh KH. M. Hasyim Asy'ari dan KH A Wahid Hasyim. Sebab itu, Pancasila sejatinya adalah merupakan cerminan ajaran luhur dari ajaran agama. Menurut Asshiddiqie, metode yang perlu dikembangkan dalam upaya revitalisasi Pancasila tidak hanya terbatas pada upaya pelatihan formal. Diperlukan instansi atau gugus tugas koordinasi yang bertugas mengembangkan pelbagai bentuk kegiatan sebagai metode untuk memasyarakatkan Pancasila dalam format yang baru. Yang terpenting adalah mengadakan sosialisasi Pancasila melalui pendidikan. ${ }^{18}$

Ada beberapa buku maupun artikel yang dapat menjadi acuan dalam melakukan kegiatan pengabdian ini. Pertama, antologi buku bertajuk Islam dan Radikalisme di Indonesia. Isinya memotret radikalisme yang terjadi di dunia Islam dan di Indonesia. Buku ini berkesimpulan bahwa radikalisme yang terjadi di dalam agama Islam disebabkan adanya politik hegemoni. Islam politik itu melahirkan organisasi-organisasi pembebasan yang radikal tetapi mereka mengalami over-reaksi sehingga masuk dalam pusaran radikalisme, seperti Hamas di Palestina, Hizbullah di Lebanon dan Partai Refah di Turki. Adapun radikalisme yang diuraikan dalam 
konteks Indonesia dalam buku ini mengkaji radikalisme di Pesantren dan organisasi masyarakat Islam. ${ }^{19}$

Kedua, buku yang diterbitkan Direktorat Jenderal Bimbingan Masyarakat Islam Kemenag RI dengan judul Radikalisme Agama dan Tantangan Kebangsaan. Buku ini membedah radikalisme dalam sejarah Islam awal sampai fenomena radikalisme modern, seperti ISIS. Pada bagian lainnya, diuraikan makna Islam sebagai agama rahmat untuk semesta alam. Korelasi antara Islam dan HAM dan NKRI juga disinggung dalam buku ini. Karena buku ini diperuntukkan sebagai pedoman bagi para penyuluh agama di Indonesia, maka di dalamnya juga ada strategi membangun harmoni kebangsaan. ${ }^{20}$

Tulisan lainnya yang membahas radikalisme adalah tulisan Abu Rokhmad bertajuk "Radikalisme Islam dan Upaya Deradikalisas Paham Radikal". Tulisan ini meneliti tentang Lembaga-lembaga pendidikan yang diduga tidak kebal terhadap pengaruh radikalisme. Penelitian ini menyimpulkan beberapa poin.c (1) Beberapa guru mengakui adanya konsep Islam radikal yang mungkin menyebar di kalangan siswa karena kurangnya pengetahuan keagamaan; (2) Unit-unit kajian Islam di sekolahsekolah berkembang baik namun tidak ada jaminan adanya kekebalan dari radikalisme karena proses belajarnya diserahkan kepada pihak ketiga; (3) Di dalam buku rujukan dan kertas kerja terdapat beberapa pernyataan yang dapat mendorong siswa untuk membenci agama atau bangsa lain. Dapat disimpulkan bahwa ada beberapa strategi deradikalisasi yang dapat diimplementasikan yaitu deradikalisasi preventif, deradikalisasi preservatif terhadap Islam moderat, dan deradikalisasi kuratif. ${ }^{21}$

Tulisan Nurhidaya yang membahas tentang meningkatnya radikalisasi gerakanagamadikalanganusia pelajar, secara tidaklangsung memberikan gambaran meningkatnya intoleransi pelajar dalam kehidupan berbangsa dan bernegara. Hal ini sangat berbahaya bagi kelangsungan hidup bangsa Indonesia yang majemuk, multikultur dan agama. Fenomena-fenomena 
radikalisasi di kalangan pelajar muncul sebagai akibat adanya globalisasi yang begitu cepat, padahal remajaremaja tersebut tinggal dalam suatu negara berkembang yang kondisinya terbalik secara ekonomi, sosial dan budaya. Masuknya informasi-informasi yang cepat serta dan arus migrasi in-out Indonesia yang begitu cepat dan tak terkendali reformasi menimbulkan shock kebudayaan (cultural shock). Penafsiran budaya dan agama juga demikian. Segala sesuatu kemudian diartikan oleh remaja secara tekstual saja. Maka terapi khusus harus segera dilakukan terkait pelajar dan keberagaamaan mereka. Sebagaimana dalam istilah agama scientology, mereka (baca: pelajar) harus segera untuk menolong diri sendiri bila ingin selamat. Sehingga remaja/pelajar tidak terjebak pada sikap keberagaamaan yang sempit. ${ }^{22}$

\section{Ngaji Pancasila Sebagai Upaya Internalisasi Pancasila}

Untuk mendapatkan out put yang diharapkan maka pengabdian masyarakat ini menggunakan metode Community Based Research CBR). ${ }^{23}$ Adapun metode pengumpulan data pada kegiatan ini meliputi wawancara dan observasi. Strategi yang digunakan dalam pengabdian masyarakat ini dengan meluncurkan program yang bernama Ngaji Pancasila. Ngaji Pancasila ini menelaah ulang nilai-nilai Pancasila yang kurang dipahami oleh obyek dampingan. Adapun langkah-langkahnya sebagai berikut:

Pertama,menyebar surat permohonan kepada Kepala Sekolah MA dan SMU se-Tangerang. Untuk program penguatan dan pemantapan, diarahkan pada dioalog interaktif (interactive dialogue). Dalam dialog interaktif ini, tim peneliti menggunakan strategi rapid assesment dan membantu memfasilitasi komunitas dampingan.Setelah dilaksanakan dialog interaktif, maka akan diperolah gambaran umum tentang permasalahan (summary problem) yang akan dijadikan pijakan berpikir (basic thinking) dalam rencana kerja (social planning).Dalam social planning, simpulan permasalahan dan kasus-kasus dikaji dan didiskusikan dengan menggunakan metode trend and change, diagram venn, kalender musim dan 
time line, analisis peristiwa kritis, pohon masalah, dan self evaluationterhadap concept mapyang dibuat.

Kedua, perencanaan program, yaitu menyusun rencana aksi dan menganalisis segala kebutuhan yang diperlukan secarabersama-sama. Proses penysusun aksi akan dimulai dengan pemetaan kebutuhanuntuk meningkatkan kemandirianya. Pemetaan betuhan pendidikan ketrampilan diharapkan mampu meningkatkan kemampuan anak jalan sehingga dapat hidup mandiri dimasa mendatang.

Ketiga, pelaksanaan program (action plan),yaitu mulai melaksanakan program-program yang sudah dirancang dalam tahapan perencanaan. Dalam pelaksanaan program, hal pertama yang dipikirkan adalah menyangkut pembiayaan, dengan demikian tim akan berupaya mencari terobosan dengan pihak luar untuk mendapatkan dana yang dibutuhkan oleh komunitas dampingan.

Keempat, refleksi dan evaluasi program. Refleksi dan evaluasi ini dilakukan setiap kali aksi selesai atau sedang dilakukan untuk melihat seberapa jauh tingkat keberhasilan dari harapan yang diinginkan. Selain itu, evaluasi program juga dilakukan untuk mengetahui seberapa jauh hasil yang telah dicapai dalam pelaksanaan program dengan tujuan mendapatkan umpan balik sebagai bahan untuk dijadikan renungan, catatan dan pemikiran dalam rangka penyusunan program pemantapan dan sosialisasi kepada pihak-pihak terkait.

Program kegiatan seminar ahlussunnah waljamaah (Aswaja) yang dibingkai dalam bentuk penelitian, pengabdian dan penyuluhan untuk siswa - siswi SMA dan Madrasah Aliyah (MA). Kegiatan itu dibagi dalam tiga indikator, yaitu pentingnya Pancasila dan NKRI, Syariat Islam dan Keindonesiaan, serta wawasan keaswajaan," Membentengi generasi muda (yang baru lulus) dari bahaya radikalisme adalah bukti pengabdian STISNU terhadap NU, berkhidmat untuk umat dan berbakti pada negeri. Kita berharap, generasi bangsa ke depannya, khususnya generasi muda tidak ada yang mengikuti organisasi radikal atas nama agama. 
Berdasarkan hasil penelitian LP2M tahun 2016 pada sekolah-sekolah di Tangerang menunjukkan adanya benih-benih radikalisme pada kalangan pelajar. Ada pemahaman yang keliru yang melanda beberapa pelajar di Tangerang mengenai konsep negara ini. Adanya pemahaman transnasional yang masuk ke Indonesia ternyata sudah mengincar para pelajar. Sebab itu, untuk fokus pengabdian kepada masyarakat terintegrasi ini para pelajar. Agar pendampingan ini berjalan secara tertib maka pendampingan dilakukan bekerjasama dengan lembaga pendidikan. Lembaga pendidikan yang dimaksud adalah Sekolah Menengah Atas (SMA) dan Setara yang ada di Kota Tangerang dan Kabupaten Tangerang

Untuk itu kegiatan pengabdian pada masyarakat terintegrasi ini dibentuk dan disesuaikan dengan kebutuhan dan pemahaman pelajar. Bentuk pengabdian kepada masyarakat terintegrasi diberi nama Ngaji Pancasila. Bentuk ini merupakan hasil diskusi dan kesepakatan Tim Peneliti dan Ketua LP2M STISNU Nusantara Tangerang.

Ngaji Pancasila ini mengandung dua makna filosofis. Pertama, Nga itu Sanga, artinya Sembilan. Ji dari siji, artinya satu. Maka Ngaji ini Sembilan dan satu. Sembilan orang yang memiliki latar belakang yang berbeda merumuskan ideologi dan falsafah Bangsa dan Negara, sehingga melahirkan satu kesepakatan yakni Pancasila. Kedua, ngaji ini berasal dari kata mengaji. Istilah ini biasa melekat pada tradisi dan civitas pondok pesantren dan santri. Ngaji ini sebuah proses pemikiran dan kajian atas sebuah kitab atau tema tertentu. Para santri saat mengaji biasanya mendengarkan penjelasan seorang kiai tentang sebuah kitab yang dikajinya. Mengaji ini memiliki sebuah tujuan berbentuk perubahan perilaku dan social pada masyarakat. Namun, ajakan perubahan itu memang tidak kentara secara kasat mata. Karena perubahan yang diinginkan dari pengajian adalah perubahan yang berangkat dari kesadaran diri sendiri, bukan dari paksaan orang lain. Berangkat dari kesadaran diri sendiri maka perubahan yang diinginkan itu akan lebih 
lama dan tegar dibanding terjadinya perubahan sebab orang lain. Ini berdasarkan al-Qur'an surah ar-Ra'd ayat 11 berikut.

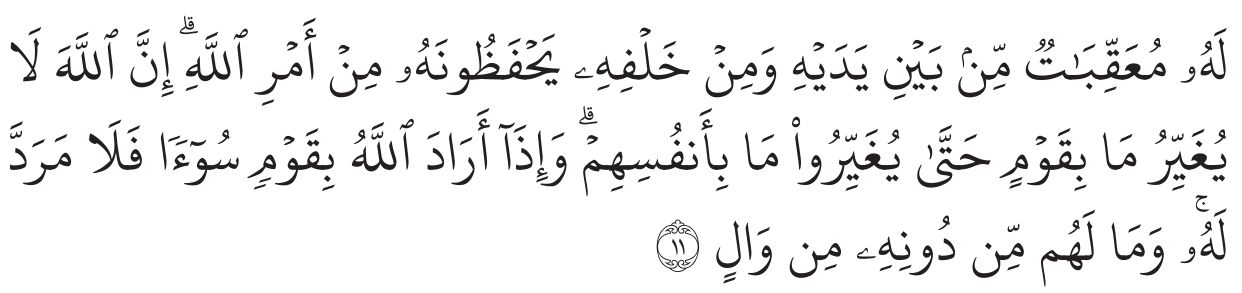

Artinya:

Bagi manusia ada malaikat-malaikat yang selalu mengikutinya bergiliran, di muka dan di belakangnya, mereka menjaganya atas perintah Allah. Sesungguhnya Allah tidak merubah keadaan sesuatu kaum sehingga mereka merubah keadaan yang ada pada diri mereka sendiri. Dan apabila Allah menghendaki keburukan terhadap sesuatu kaum, maka tak ada yang dapat menolaknya; dan sekali-kali tak ada pelindung bagi mereka selain Dia. (QS. Ar-Ra'd: 11)

Karena begitu banyaknya sekolah yang ada di Kota Tangerang dan Kabupaten Tangerang, maka pengabdian ini tidak dilaksanakan pada semua sekolah. Sekolah-sekolah itu diambil berdasarkan tingkat sejauhmana benih radikalisme itu menyerang para pelajar. Kemudian, sekolah-sekolah itu dikirimi surat perihal kerjasama pengabdian dalam bentuk Ngaji Pancasila. Ada lima lembaga pendidikan yang menjadi lokasi pengabdian kepada masyarakat.

Pertama, Yayasan An-Nisiniyyah yang memiliki 2 lembaga pendidikan, Sekolah Menengah Pertama (SMP) dan Sekolah Menengah Kejuruan (SMK). Sekolah ini berlokasi di Jl. Marsekal Surya Darma Baru, Selapajang Jaya, Neglasari, Kota Tangerang, Banten 15127. Adapun izin operasional 421.1/KEP.02-SMK/BPPMPT/2. ${ }^{24}$

Kedua, Yayasan al-Hikmah. Al-Hikmah berdiri pada tahun 1922. Di dalamnya ada SMP dan SMA. Yayasan ini berlokasi di Jalan KH Abdurrahman No. 1 Pendawa Kec. Kresek Kab Tangerang Banten 15620. Visi yang diusung yayasan ini adalah Mulia dalam akhlaqul karimah, 
kuat dalam spiritual, unggul dalam prestasi dan tampil sebagai teladan. Ketiga, SMAN $20 \mathrm{Kab}$ Tangerang. Sekolah ini terletak di Jalan Raya Pakuhaji KM. 2 Kab. Tangerang, RT/RW. 2/2, Dsn. Kp. Empetan, Ds./Kel Buaran Bambu, Kec. Pakuhaji, Kab. Tangerang, Prov. Banten. ${ }^{25}$ Keempat, SMAN 21 Kab. Tangerang. Alamatnya di Jalan Cirarab no. 5, RT/RW. 3/1 Desa Sukadiri Kec. Sukadiri, Tangerang, Banten 15530. ${ }^{26}$ Kelima, SMAS Babussalam yang beralamat di Jalan. Merdeka Raya, Pabuaran, Kec. Karawaci, Kota Tangerang Prov. Banten. ${ }^{27}$

Pendidikan Kewarganegaraan kepada pelajar di sekolah-sekolah belum memberikan pemahan yang utuh tentang konsep dan ideology bangsa dan negara. Itu terbukti dari dampingan yang hanya hapal pasal-pasal dari Pancasil tanpa memahami dari setiap pasalnya. Sejarah pembentukkan Pancasila juga masih menjadi perhatian. Sebab itu, dalam proses pengabdian ada beberapa materi yang disampaikan kepada peserta dampingan. Pertama, Pancasila dan Islam. Tema ini diarahkan pada kesesuaian Pancasila dengan Islam. Setiap pasal-pasal dalam Pancasila itu selaras dengan nilai-nilai yang ada dalam Islam. Kedua, Nilai-Nilai Luhur Pancasila dan Implementasinya. Pelajar tidak hanya hapal pasal-pasalnya, tetapi juga bisa menerapkan dalam kehidupan sehari-hari dalam beragama, berbangsan dan bernegara. Ketiga, Ulama dan Pancasila. Bagian ketiga ini menerangkan tentang sejarah keterlibatan para Ulama Nusantara dalam pembentukkan negara. Keempat, Islam Ramah dan Aswaja.

Pendampingan dilakukan dengan menyampaikan empat tema itu. Keempatnya disajikan dan disesuaikan dengan tingkat pemahaman pelajar. Diawali dengan penyampaian materi, tanya jawab dan pemberian hardcopy materi pengabdian. Dari peserta dampingan itu banyak yang tidak tahu keterlibatan ulama dalam perumusan Pancasila dan kemerdekaan Republik Indonesia. Sebagian mereka juga tidak mengetahui kesesuaian antara Pancasila dan Islam. Padahal, setiap pasal dalam Pancasila itu sesuai dengan al-Qur'an. Artinya, Pancasila mengandung nilai-nilai Qur'ani. Hal ini yang belum banyak 
yang mengetahui. Mereka termakan hoax dan isu yang berkembang bahwa Pancasila itu tidak sesuai dengan Islam. Sebab itu, perlu adanya implementasi dari setiap pasal itu, agar pelajar memahami jati diri bangsa dan negaranya secara utuh.

\section{a. Penerapan pada sila pertama}

Pada sila yang pertama ini merupakan nilai - nilai yang menerapkan tentang hubungan kita dengan Tuhan.. Salah satu contoh penerapan yang paling sederhana adalah menjaga hubungan erat dengan sesama mahkluk hidup, menghormati bagi yang beragama lain, Kemudian dengan kita beribadah kepada Allah SWT (yang beragama Islam), seperti sholat wajib sebanyak 5 waktu selalu dilaksanakan, mengaji, dzikir, sholawat, dll. Itu sudah merupakan penerapan dalam nilai - nilai penerapan pancasila pada sila pertama.

\section{b. Penerapan pada sila kedua}

Pada sila kedua ini yang berbunyi kemanusiaan yang adil dan beradab. Penerapan pada sila ini erat kaitannya dengan kehidupan sosial yang ada dilingkungan kita. Pada intinya dalam sila ke-2 ini nilai - nilai yang terkandung didalamnya keadilan dan kemanusiaan. Cara penerapan sila ini untuk pemuda adalah menolong teman yang sedang kesusahan, hal ini telah mencakup pada cinta sesama manusia. Kemudian mengungkapkan kebenaran demi keadilan itu salah satu hal yang sulit dilakukan oleh kalangan remaja.

\section{c. Penerapan pada sila ketiga}

Penerapandalamsilaketigamungkinmudahdilakukanolehkalangan remaja, meskipun sudah menerapkannya namun penerapannya banyak yang salah bahkan lari ke hal yang negatif. Contoh penerapannya yaitu dalam sebuah kelompok atau organisasi. Kekompakan merupakan hal yang terpenting dalam kelompok, karena kekompakan dalam kelompok bisa menyatukan anggota kelompok. Mementingkan kepentingan 
kelompok dari pada kepentingan diri sendiri, mungkin ini yang sulit diterapkan pada suatu kelompok.

d. Penerapan pada sila keempat

Pada sila keempat diperlukan sikap yang lebih dewasa untuk penerapannya, karena berhubungan dengan musyawarah atau salah satu cara yang ditempuh untuk memecahkan suatu masalah. Musyawarah umumnya dilakukan ketika hendak mengadakan kegiatan atau ketika kita menemukan masalah. Musyawarah ini merupakan salah satu cara penerapan nilai - nilai pancasila pada sila keempat.

e. Penerapan pada sila kelima

Pada sila kelima ini erat hubungannya dengan hak dan kewajiban kita sebagai makhluk sosial. Contoh penerapannya pada remaja misalya seperti bersikap adil terhadap teman, menghormati hak - hak orang lain, dan menolong sesama.

Setelah melakukan Ngaji Pancasila Tim Pengabdian melakukan komunikasi dengan pihak sekolah, khususnya kepada Kepala Sekolah. Hasil pembicaraan dengan kepala-kepala sekolah menghasilkan beberapa point. Pertama, Melibatkan dosen STISNU Nusantara dalam memberikan materi kebangsaan dan keislaman dalam kegiatan ekstrakurikuler. Kedua, memberikan pelajar konsultasi Islam yang ramah. Ketiga, menjalin kerja sama untuk melakukan Ngaji Pancasila setiap tahunnya.

Dengan adanya kesepahaman, itu menunjukkan besarnya apresiasi pihak sekolah terhadap pengabdian masyarakat yang diadakan STISNU Nusantara. Banyak yang mengapresiasi adanya Ngaji Pancasila yang diadakan dosen-dosen STISNU Nusantara. Salah satunya, Kepala Sekolah SMAS Al-Hikmah H Fahad. Menurutnya, kegiatan Ngaji Pancasila ini menambah rasa nasionalisme para pelajar al-Hikmah. Dan membantu sekolah dalam memberikan pengajaran tentang kebangsaan. ${ }^{28}$ 


\section{E. Penutup}

Berdasarkan pengabdian yang dilakukan terdapat beberapa aspek yang perlu diperhatikan. Pertama, pelajar ini sebagai assetbangsa ke depan. Maka perlu diberikan perhatian yang benar. Penguatan Kebangsaan dan Pancasila ini perlu dilakukan bagi semua pelajar di Indonesia. Kedua, pemerintah daerah melalui Dinas Pendidikan dan Kementrian Agama setempat perlu merumuskan kurikulum ekstrakurikuler yang dapat meningkatkan rasa nasionalisme dan kebangsaan para pelajar. Ketiga, mempersempit ruang gerak ideologi radikalisme di kalangan pelajar harus menjadi perhatian bersama. Keempat, banyak pelajar yang belum mengerti terkait korelasi antara Pancasila dan Islam, dan keduanya tidak saling bertentangan. 


\section{Daftar Pustaka}

Az-Za'balawi, M. Sayyid Muhammad. 2007. Pendidikan Remaja antara Islam \& Ilmu Jiwa. Jakarta: Gema Insani.

Banks, Sarah. 2012. Community Based Participatory Research A Guide to Ethical Principles and Practice. United Kingdom: Durham University.

Musa, Ali Masykur. 2014. Membumikan Islam Nusantara: Respons Islam Terhadap Isu - Isu Aktual. Jakarta: Serambi Ilmu Semesta.

Nurhidayah.2014."Dekonstruks FanatismeKeagamaanBerbasisSekolah:: Alternatif Pendekatan Deradikalisasi Gerakan Keagamaan di Tingkat Usia Pelajar Muslim" dalam An-Nidzam, Volume 1, Nomor 2, Mei-Agustus.

Qustulani, Muhammad, and Muhammad Sartibi, ed. 2016. Peran NilaiNilai Luhur Kebangsaan Dalam Menangkal Paham Radikalisme. Tangerang: PSP Nusantara Press.

Rokhmad, Abu. 2012. "Radikalisme Islam Dan Upaya Deradikalisasi Paham Radikal." Walisongo: Jurnal Penelitian Sosial Keagamaan 20, no. 1 May 30. Accessed September 16, 2018. http://www.journal. walisongo.ac.id/index.php/walisongo/article/view/185.

Sarwono, Sarlito Wirawan. 2012. Terorisme di Indonesia: Dalam Tinjauan Psikologi. Ciputat: Pustaka Alvabet.

Sudjito, Zeth Sahuburua, dkk. 2014. Prosiding Kongres Pancasila VI: Penguatan, sinkronisasi, harmonisassi, integrasi pelembagaan dan pembudayaan Pancasila dalam rangka memperkokoh kedaulatan bangsa. Yogyakarta: Pusat Studi Pancasila UGM.

Tangerang, Pemerintah Kota. “Website Resmi Pemerintah Kota Tangerang." Accessed September 21, 2018. https://www. tangerangkota.go.id/. 
Turmudzi, Endang, and Riza Sihbudi, ed. 2005. Islam dan radikalisme di Indonesia. Jakarta: LIPI Press.

Zarkasyi, Jaja, and Thobib Al- Asyhar. 2014. Radikalisme agama tantangan kebangsaan. Direktorat Jenderal Bimbingan Masyarakat Islam, Kemenag RI.

"Mendagri: Ada Kepala Sekolah Larang Murid Hormat Bendera Dan Nyanyi Indonesia Raya - Kompas.Com." Accessed September 16, 2018. https://nasional.kompas.com/read/2017/10/18/15004381/ mendagri-ada-kepala-sekolah-larang-murid-hormat-bendera-dannyanyi-indonesia. 


\section{Endnotes}

1. Baca, Lukman Hakim Saifuddin, "Menuju Islam Indonesia yang Ramah dan Moderat" dalam Jaja Zarkasyi and Thobib Al- Asyhar, Radikalisme agama tantangan kebangsaan (Direktorat Jenderal Bimbingan Masyarakat Islam, Kemenag RI, 2014), h. vii.

2. Masalah radikalisme dalam kontestasi politik Indonesia pendukungnya tambah banyak. Akan tetapi, di antara gerakan-gerakan mereka terdapat perbedaan. Ada yang hanya sekedar memperjuangkan formalisasi syariat Islam tanpa mendirikan negara Islam. Ada juga yang ingin merubah NKRI menjadi negara Islam. BacaEndang Turmudzi and Riza Sihbudi, eds., Islam dan radikalisme di Indonesia (Jakarta: LIPI Press, 2005).Lihat juga, Abu Rokhmad, "RADIKALISME ISLAM DAN UPAYA DERADIKALISASI PAHAM RADIKAL," Walisongo: Jurnal Penelitian Sosial Keagamaan 20, no. 1 (May 30, 2012): 79-114, accessed September 16, 2018, http://www.journal. walisongo.ac.id/index.php/walisongo/article/view/185.

3. Ini berdasarkan atas penelitian yang dilakukan Bambang Pranowo pada tahun 2011 terhadap 100 SMPn dan SMA yang ada di Jakarta. Sebanyak 84.80 persen siswa SMP-SMA setuju syariat Islam diberlakukan, $25.80 \%$ menyatakan Pancasila tidak relevan menjadi dasar negara dan $48.90 \%$ bersedia ikut aksi kekerasan terkait agama dan moral. Baca, Sarlito Wirawan Sarwono, Terorisme di Indonesia: Dalam Tinjauan Psikologi (Ciputat: Pustaka Alvabet, 2012), h. 87.

4. M. Sayyid Muhammad Az-Za'balawi, Pendidikan Remaja antara Islam E Ilmu Jiwa (Gema Insani, 2007), h. 15.

5. Menurut Sarwono terdapat semblian bentuk ciri radkalisme yang menyebar di kalangan pelaar. Pertama, para aktivis radkal agama menanamkan kebencan terhadap negara dan pemerntahan. Kedua, para pelajar diajarkan 
menolak menyanyikan lagu-lagu kebangsaan dan menghormat bendera. Ketiga, ikatan emosiona kepada ustadz, senor dan kelompoknya lebih kuat daripada ikatan pada keluarga dan almamaternya. Keempat, kegiatan yang mereka lakukan dalam melakukan pengajian dan kaderisasi bersifat tertutup. Kelima, para pelajar anggota gerakan radikal diharuskan membayar uang penebusan dosa. Keenam, mengenakan pakaian secara khas yang menurut mereka adalah versi Islami. Ketujuh, menganggap kafir dan fasik orang lain yang belum bergabung dengan kelompoknya. Kedelapan, enggan mendengarkan ceramah dari kelompok lain. Kesembilan, sebagian dari palajar bersikukuh mengikuti gerakan radikalisme agama. Baca, Wirawan Sarwono, Terorisme di Indonesia, h. 122.

6. "Mendagri: Ada Kepala Sekolah Larang Murid Hormat Bendera Dan Nyanyi Indonesia Raya - Kompas.Com," accessed September 16, 2018, https://nasional.kompas.com/read/2017/10/18/15004381/mendagri-adakepala-sekolah-larang-murid-hormat-bendera-dan-nyanyi-indonesia.

7. Sudjito et al., Prosiding Kongres Pancasila VI: Penguatan, sinkronisasi, harmonisassi, integrasi pelembagaan dan pembudayaan Pancasila dalam rangka memperkokoh kedaulatan bangsa (Yogyakarta: Pusat Studi Pancasila UGM, 2014), h. 250.

8. Letak Kota Tangerang tersebut sangat strategis karena berada di antara Ibukota Negara DKI Jakarta dan Kabupaten Tangerang. Sesuai dengan Instruksi Presiden Nomor 13 Tahun 1976 tentang Pengembangan Jabotabek (Jakarta, Bogor, Tangerang, Bekasi), Kota Tangerang merupakan salah satu daerah penyangga Ibukota Negara DKI Jakarta. Pemerintah Kota Tangerang, “Website Resmi Pemerintah Kota Tangerang," accessed September 21, 2018, https://www.tangerangkota.go.id/.

9. Pemerintah Kota Tangerang, “Website Resmi Pemerintah Kota Tangerang," accessed September 21, 2018, https://www.tangerangkota.go.id/.

10. Muhammad Qustulani and Muhammad Sartibi, eds., Peran Nilai-Nilai Luhur Kebangsaan Dalam Menangkal Paham Radikalisme (Tangerang: PSP Nusantara 
Press, 2016), h. 101.

11. Ali Masykur Musa, Membumikan Islam Nusantara: Respons Islam Terhadap Isu - Isu Aktual (Jakarta: Serambi Ilmu Semesta, 2014), h. 286.

12. http://www.umm.ac.id/id/pages/banten/data-sma-dan-smk-kotatangerang.html. Diakses pada hari Kamis, 12 Maret 2018 pukul 20.32 WIB.

13. Qustulani and Sartibi, Peran Nilai-Nilai Luhur Kebangsaan Dalam Menangkal Paham Radikalisme, h. 80-85.

14. Menurut KH Hasyim Muzadi, pada dasarnya orang yang berpikir mendalam sampai ke akar-akarnya itu diperbolehkan. Selama pendapat dan pembelaan itu dalam tataran wacana atau pemikiran itu tidak akan menjadi persoalan publik. Baca, Zarkasyi and Asyhar, Radikalisme agama tantangan kebangsaan, h. 3-4.

15. Zarkasyi and Asyhar, Radikalisme agama tantangan kebangsaan, h. 10.

16. Zarkasyi and Asyhar, Radikalisme agama tantangan kebangsaan, h. 10.

17. Sarwono, Terorisme di Indonesia, h. 120-121.

18. Prihandono Wibowo, "Urgensi Revitalisasi Pancasila Sebagai Upaya Mengatasi Radikalisme Agama" dalam Sudjito et al., Prosiding Kongres Pancasila VI, h. 253.

19. Endang Turmudi dan Riza Sihbudi (ed.), Islam dan Radikalisme di Indonesia (Jakarta: LIPI Press, 2005), h. 25.

20. Jaja Zarksyi \& Thobib al-Asyhar (ed.), Radikalisme Agama E Tantangan Kebangsaan (Jakarta: Dirjen Bimas Islam Kemenag RI, 2014), h. 23.

21. Abu Rokhmad," Radikalisme Islam dan Upaya Deradikalisasi Paham Radikal" dalam Walisongo, Volume 20, Nomor 1, Mei 2012, h. 13. 
22. Nurhidayah, "Dekonstruks Fanatisme Keagamaan Berbasis Sekolah:: Alternatif Pendekatan Deradikalisasi Gerakan Keagamaan di Tingkat Usia Pelajar Muslim" dalam An-Nidzam, Volume 1, Nomor 2, Mei-Agustus 2014, h. 26 .

23. M enurut Sarah Bank, CBR adalah penelitian yang dilakukan atas sebuah komitmen dari masyarakat untuk memberikan dukungan kekuatan, sumber daya, dan juga keterlibatan dalam proses penelitian dalam rangka menghasilkan produk penelitian yang bermanfaat bagi mereka dan juga peneliti yang terlibat. Baca, Sarah Banks, Community Based Participatory Research A Guide to Ethical Principles and Practice (UK: Durham University, 2012), h. 6.

24. Visi SMP-SMK An-Nisiniyyah, Menjadikan SMP - SMKAn-Nisiniyyah sebagai lembaga pendidikan dan pelatihan (pembelajaran) yang professional dan mandiri dan mewujudkan Competence, Conscience, Compassion. Lihat, brosur Yayasan An-Nisiniyyah. Lihat juga, http://pmp.dikdasmen. kemdikbud.go.id/sekolah/857d626415b4c8dd8de1. Diakses pada tanggal 24/9/2018 pada pukul 09.30 wib. Lihat juga http://dapo.dikdasmen. kemdikbud.go.id/sekolah/857d626415b4c8dd8de1. Diakses pada tanggal 24/9/2018 pada pukul 09.30 wib.

25. Lihat, http://pmp.dikdasmen.kemdikbud.go.id/sekolah/0b1f6c7af36edba1ca62. Diakses pada tanggal 24/9/2019 pada pukul 12.28 wib. Lihat juga, http://sekolah. data.kemdikbud.go.id/index.php/chome/profil/1AB6001A-476D-418A-9819221E0C8BC5FB. Diakses pada tanggal 24/9/2019 pada pukul 12.28 wib.

26. Lihat, http://dapo.dikdasmen.kemdikbud.go.id/sekolah/ ED97DDDD99DC71F3CF40. Diakses pada tanggal 24/9/2018 pukul 12.47 wib. Lihat juga pada http://pmp.dikdasmen.kemdikbud.go.id/sekolah/ ed97dddd99dc71f3cf40. Diakses pada tanggal 24/9/2018 pukul 12.47 wib.

27. Lihat, http://sekolah.data.kemdikbud.go.id/index.php/chome/ profil/46593408-18EA-4B18-8A12-0EC452D1731E. Diakses pada tanggal 
25/9/2018 pukul 14.27 wib. Lihat juga pada http://dapo.dikdasmen. kemdikbud.go.id/sekolah/B854A10E6ED673095030. Diakses pada tanggal 25/9/2018 pukul 14.28 wib.

28. Testimoni H Fahad Kepalas Sekolah SMAS Al-Hikmah Kresek, di Ruangan Kepala Sekolah SMAS Al-Hikmah, Pada tanggal 27 Agustus 2018, pukul 14.30 . 